Acta Regionalia et Environmentalica 2

Nitra, Slovaca Universitas Agriculturae Nitriae, 2016, pp. 31-34

\title{
SIGNIFICANT CORRELATIONS DEPENDENCE OF HIGH-RISK CHEMICAL ELEMENTS IN THE ENVIRONMENT
}

\author{
Jana URMINSKÁ \\ Slovak University of Agriculture in Nitra, The Slovak Republic
}

\begin{abstract}
With the development of industry, agriculture, exploitation of natural sources and with boom of settlement density, the environment is being affected by potentially toxic elements; the phenomenon is consequently reflected on human health. Cadmium is a high risk element for the whole environment. The aim of this research was to analyse and evaluate sediments of selected water reservoirs during the ten-year period in order to determine the concentrations of selected, potentially toxic elements. For statistical processing, the correlation coefficient by the Spearman method and the analysis of the index were used. Sediments are reliable indicators of environmental pollution. The analyses of the sediment samples were carried out by the flow electrochemistry and the atomic absorption spectrometry methods. The total concentration of $\mathrm{Cd}$ in sediments was up to $22.60 \mathrm{mg} \mathrm{kg}^{-1}$ of dry matter. $\mathrm{pH} / \mathrm{KCl}$ was marked in the range from 5.6 to 7.2. From statistical processing of sediments data by Spearman, we determined the dependencies between $\mathrm{Cd}$ and the following elements: $\mathrm{As}, \mathrm{Cu}, \mathrm{Hg}, \mathrm{Pb}$ and $\mathrm{Zn}$. The relations between $\mathrm{Cd}$ and the following elements: $\mathrm{Pb}, \mathrm{As}$ and $\mathrm{Cu}$ were very highly positive.
\end{abstract}

Keywords: Analysis of the index, cadmium, correlation coefficient by Spearman, $\mathrm{pH} / \mathrm{KCl}$, sediment

Statistical methods are very important evaluation indicator of scientific observation.They represent an integral part of the results. The Spearman's rank correlation coefficient is a measure of dependence based on measurement of the correlation between rankings (Stehlíková, 1999). The indices analysis represents an analysis of phenomena and processes we want to assess from the perspective of their development dynamics, and compare the indicators in time, place and in light of their factual definition (Obtulovič, 2010). The potentially toxic elements are considered as elements relatively widely present in the Earth's crust; they are being mined and exploited in average quantity; they constitute a content of materials people are coming into contact with; they have got toxic effects on organisms and they cause undesirable effects in biogeochemical cycle (Fergusson, 1990). Cadmium is a very important risk element for the whole environment. Cadmium is a second row transition metal belonging to the group 12 of the periodic table, along with $\mathrm{Zn}$ and $\mathrm{Hg}$. The chemistry of cadmium is most similar to that of $\mathrm{Zn}$. Cadmium is a low-abundance, chalcophile element that most commonly occurs as a substitute for $\mathrm{Hg}, \mathrm{Cu}, \mathrm{Pb}$ and $\mathrm{Zn}$ in sulphide minerals (Fergusson, 1990; Salminen et al., 2005; Resongles et al., 2014). Increased Cd values are generally indicative of sulphide mineralisation. Since $\mathrm{Cd}$ has strong chalcophile affinities, it may be used to validate a questionable $\mathrm{Zn}$ anomaly. In the surface environment, $\mathrm{Cd}$ is most mobile under oxidising conditions at $\mathrm{pH}$ levels below 8. Consequently, the mobility of $\mathrm{Cd}$ released from minerals is likely to be high, especially during conditions of increased flow, when $\mathrm{pH}$ is lower and $\mathrm{Cd}$ more readily leached (Khun et al., 2008). Mobility of cadmium and its bio accessibility has the highest value of $\mathrm{pH}$ in an acidic medium of sediments as it was ranged from 4.5 to 5.5 (Makovníková et al., 2006). On the other hand, cadmium is less mobile in alkaline medium. It has a tendency to precipitate on the surface of clay minerals if its value of $\mathrm{pH}$ is in alkaline medium. Mobility of cadmium is controlled by solubility of $\mathrm{CdCO}_{3}$ or $\mathrm{Cd}_{3}\left(\mathrm{PO}_{4}\right)_{2}$, if value of $\mathrm{pH}>7.5$. However, the sulphate and carbonate of $\mathrm{Cd}$ are less soluble than those of $\mathrm{Zn}$, so $\mathrm{Cd}^{2+}$ mobility is more restricted in carbonate-rich sediments and soil (Salminen et al., 2005). Percentage level of cadmium loadings in sewage sludge represent problems from the perspective of their disposal and limitation or prevention of sludges being applied to land as fertilisers. Cadmium has no essential biological function, but it tends to accumulate in plants and aquatic biota, with consequent problems of toxicity. It is toxic to humans through the inhalation of dust, causing lung damage, and may cause cancer from longterm exposure (WHO); it is also teratogenic and embryocidal (Salminen et al., 2005; Khun et al., 2008). This study focuses on the analysis of sediments of selected water reservoirs of the Piargs group. Based on the results gained by chemical analysis we aim to predict possible adverse effects on the environment. Taking into account the environment, we also aim to determine correlation, the statistical significance of dependencies of analysed environmental parameters.

\section{Material and methods}

The status of the monitored areas was assessed based on the observation and chemical analysis of sediments from 
the selected water reservoirs called the Piargs group. The statistical analysis was performed by Spearman's rank correlation coefficient (Stehlíková, 1999) and indices analysis (Obtulovič, 2010). The Spearman's rank correlation coefficient ( $\rho s)$ is a measure of dependence based on measurement of the correlation between rankings:

$$
\rho_{s}=1-\frac{6 \sum_{i=1}^{n} d_{i}^{2}}{n\left(n^{2}-1\right)}
$$

The coefficient indicates the interdependence between two elements, e.g. interdependence between the concentration of two specific elements. $\sum d_{i}(i=1,2$, $\ldots, n)$ means the sum of the differences between ranking, $\mathrm{n}$ represents the number (eg. number of monitored community). The indices analysis represents an analysis of phenomena and processes we want to assess from the perspective of their development dynamics, and compare the indicators in time, place and in light of their factual definition (Obtulovič, 2010). Sediment samples were taken once a year in autumn from the selected water reservoirs. The samples were taken mainly with a hand sampler from a part of the bank. The weight of all samples was up to $5 \mathrm{~kg}$. The samplings were extracted from a dam sediment and from the settled sediment located opposite the dam. One analysed sample represents five samplings from one sampling location, while the sample material was mixed in clean polyethylene containers. The sediment samples were homogenised and dried at $40{ }^{\circ} \mathrm{C}$ under bulbs during the period of 48 hours. The samples were subsequently grounded into fine-textured soil by a soil mill (VEB Thurm ZG 1). To determine the content of analysed element $\mathrm{Cd}$, the sedimental fractionation with the texture under $0.125 \mathrm{~mm}$ was used. The analysis of samples in leachate was carried out according to existing legislative measures. The flow electrochemical method and the atomic absorption spectrometric method were used to analyse chemical elements in leachate. The analysis of samples in leachate to find out values of exchange reactions in soil was carried out by the machine "pH meter- JENWAY 3510". It was calibrated on 3 point $\mathrm{pH}$ calibration (buffer) $(\mathrm{pH} \mathrm{4,} \mathrm{7,}$ 9). The values of exhange reaction in soil were determined by potentiometry in aqueous suspension and in $1 \mathrm{~mol} \mathrm{dm}^{-3}$ from the solution $\mathrm{KCl}$ according to the methodology by Fiala et al. (1999) in Urminská (2011).

\section{Results and discussion}

The monitored area is situated in the region of hydrothermally converted volcanic rocks and in the region with anthropogenic activities. In the study area of the selected water reservoirs in the Banská Štiavnica region, the samples were collected from 2001 to 2010, and we found the following concentrations of cadmium to $22.60 \mathrm{mg} \mathrm{kg}^{-1} \mathrm{Cd}$ of dry matter, As to 0.481 $\mathrm{mg} \mathrm{kg}^{-1}$ As of dry matter, Cu to $14.0 \mathrm{mg} \mathrm{kg}^{-1} \mathrm{Cu}$ of dry matter,

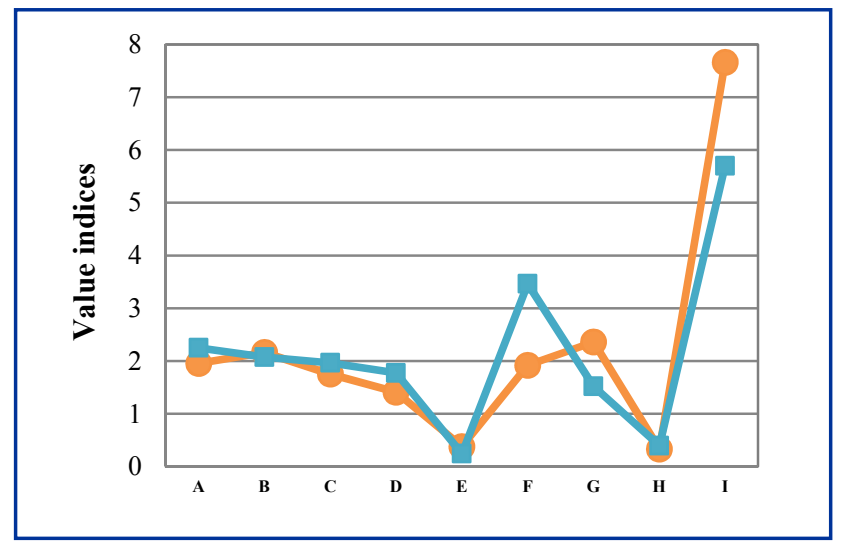

Figure 1 Value indices of cadmium in Počúvadlo Lake

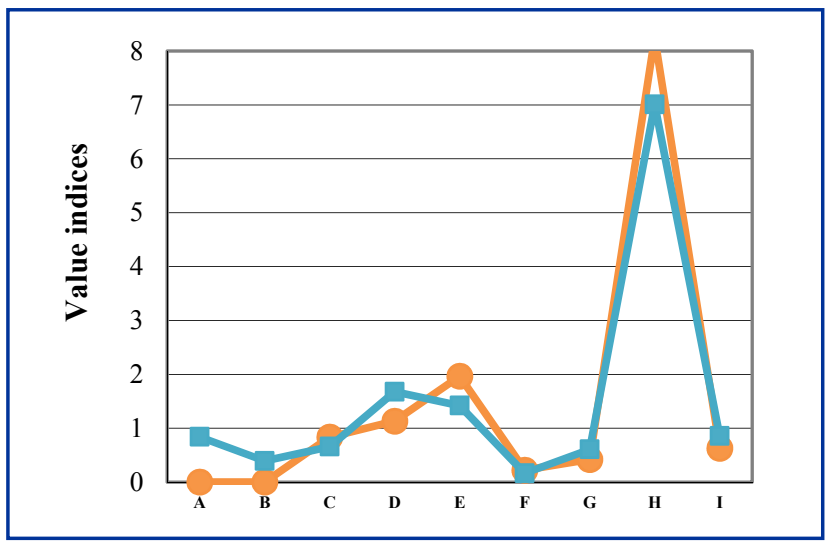

Figure 3 Value indices of cadmium in Great Richňava Lake

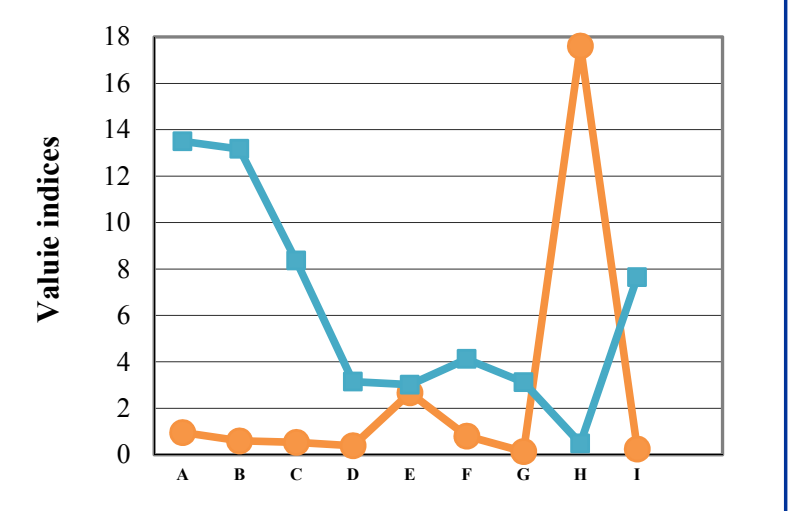

Figure 2 Value indices of cadmium in Little Richňava Lake Note for Figs 1-4: dam sampling points, opposite to dam sampling points

A - 2002/2001, B - 2003/2002, C - 2004/2003, D- 2005/2004, E- 2006/2005, F- 2007/2006, G - 2008/2007, H- 2009/2008, I- 2010/2009 
Table 1 The Spearman coefficients - relationship between $\mathrm{Cd}$ and selected elements and pH/KCl for years 2001 to 2010

\begin{tabular}{|l||c|c|c|c|c|c|}
\hline \multicolumn{1}{|c|}{} & $\mathbf{A s}$ & $\mathbf{C u}$ & $\mathbf{H g}$ & $\mathbf{P b}$ & $\mathbf{Z n}$ & $\mathbf{p H} / \mathbf{K C l}$ \\
\hline \hline $\mathbf{C d}$ & $0.30720^{*}$ & 0.68832 & 0.34844 & 0.63556 & 0.10185 & 0.94161 \\
\hline $\mathbf{2 0 0 1}$ & $0.4592^{* *}$ & 0.0591 & 0.3976 & 0.0903 & 0.8103 & 0.0584 \\
\hline $\mathbf{C d}$ & 0.44298 & 0.5385 & 0.33246 & 0.16393 & 0.60269 & 0.01507 \\
\hline $\mathbf{2 0 0 2}$ & 0.0982 & $\mathbf{0 . 0 3 8 4}$ & 0.2260 & 0.5594 & $\mathbf{0 . 0 1 7 4}$ & 0.9670 \\
\hline $\mathbf{C d}$ & 0.95589 & 0.73898 & 0.63585 & 0.61677 & -0.05746 & -0.72102 \\
\hline $\mathbf{2 0 0 3}$ & $\mathbf{0 . 0 0 6 2}$ & $\mathbf{0 . 0 3 6 2}$ & 0.0901 & 0.1034 & 0.8925 & 0.2790 \\
\hline $\mathbf{C d}$ & 0.15579 & 0.43189 & 0.58941 & 0.96436 & 0.17063 & 0.42835 \\
\hline $\mathbf{2 0 0 4}$ & 0.7126 & 0.2853 & 0.1241 & $\mathbf{0 . 0 0 0 1}$ & 0.6862 & 0.5716 \\
\hline $\mathbf{C d}$ & 0.86091 & 0.85698 & 0.73126 & 0.91483 & 0.77906 & 0.08595 \\
\hline $\mathbf{2 0 0 5}$ & $\mathbf{0 . 0 0 6 0}$ & $\mathbf{0 . 0 0 6 6}$ & $\mathbf{0 . 0 3 9 3}$ & $\mathbf{0 . 0 0 1 4}$ & $\mathbf{0 . 0 2 2 7}$ & 0.9141 \\
\hline $\mathbf{C d}$ & -0.32644 & 0.28546 & 0.31187 & 0.04819 & 0.68000 & -0.11725 \\
\hline $\mathbf{2 0 0 6}$ & 0.4300 & 0.4931 & 0.4520 & 0.9098 & 0.0635 & 0.8828 \\
\hline $\mathbf{C d}$ & 0.04012 & 0.09093 & 0.47651 & 0.16492 & -0.09089 & -0.29662 \\
\hline $\mathbf{2 0 0 7}$ & 0.9249 & 0.8304 & 0.2326 & 0.6963 & 0.8305 & 0.7034 \\
\hline $\mathbf{C d}$ & 0.8397 & 0.73988 & 0.61688 & 0.58665 & 0.80806 & 0.71974 \\
\hline $\mathbf{2 0 0 8}$ & $\mathbf{0 . 0 0 9 1}$ & $\mathbf{0 . 0 3 5 9}$ & 0.1033 & 0.1263 & $\mathbf{0 . 0 1 5 2}$ & 0.2803 \\
\hline $\mathbf{C d}$ & 0.90936 & 0.92409 & 0.18673 & 0.49515 & 0.71726 & 0.79829 \\
\hline $\mathbf{2 0 0 9}$ & $\mathbf{0 . 0 0 1 7}$ & $\mathbf{0 . 0 0 1 0}$ & 0.6579 & 0.2122 & $\mathbf{0 . 0 4 5 2}$ & 0.2017 \\
\hline $\mathbf{C d}$ & 0.79313 & 0.10374 & 0.60748 & 0.91645 & 0.66909 & 0.39927 \\
\hline $\mathbf{2 0 1 0}$ & $\mathbf{0 . 0 1 8 8}$ & 0.8069 & 0.1102 & $\mathbf{0 . 0 0 1 4}$ & 0.0696 & 0.6007 \\
\hline
\end{tabular}

* the Spearman coefficient, ${ }^{* *}$ level of significance

$\mathrm{Hg}$ to $0.49 \mathrm{mg} \mathrm{kg}^{-1} \mathrm{Hg}$ of dry matter, $\mathrm{Pb}$ to $59.04 \mathrm{mg} \mathrm{kg}^{-1} \mathrm{~Pb}$ of dry matter and $\mathrm{Zn}$ to $98.0 \mathrm{mg} \mathrm{kg}^{-1} \mathrm{Zn}$ of dry matter. $\mathrm{pH} /$ $\mathrm{KCl}$ in the range from 5.6 to 7.2 (Urminská, 2011). pH is a very interesting key parameter in the evaluation of mobility and bio accessibility of elements in the environment (Barančíková, 1998; Makovníková et al., 2006). Most of the risk elements intensely migrate in the environment, when $\mathrm{pH}$ is under 7 (Khun et al., 2008). These sediments showed higher amounts of cadmium as a high risk factor in the environment. According to the index analysis observation, the monitored period from 2001 to 2010 showed the values of moderate dynamics (Figs 1-4).

The most significant index values were found in the water reservoir Počúvadlo in 2006. They were decreased by $75.64 \%$ compared to year 2005 and index values were increased by $666.15 \%$ in 2010 compared to 2009 . For the location Malá Richňava, the index values were decreased by $83.63 \%$ in 2007 compared to 2006 , the index values were increased by $725.24 \%$ in 2009 compared to 2008. In addition, significant index values were found in the water reservoir Vel'ká Richňava in 2008. They were decreased by $86.64 \%$ compared to year 2007 and index values were increased by $1661.01 \%$ in 2009 compared to 2008. Moreover, index values with the decrease of $83.85 \%$ in 2006 compared to 2005 and index values with the increase of $1180.76 \%$ in 2009 compared to 2008 were observed in the water reservoir Windšachta. The development is highly dynamic and reflective to the environment, because water reservoirs are affected by chemical and physical factors.

The Spearman coefficients - correlation between $\mathrm{Cd}$ and selected elements and $\mathrm{pH} / \mathrm{KCl}$ for years 2001 to 2010 are shown in table 1.
The most significant correlation between $\mathrm{Cd}$ and $\mathrm{Cu}$ was shown in 2002. The value of the Spearman's rank correlation coefficient for concentration of dependencies between $\mathrm{Cd}$ and $\mathrm{Cu}$ was 0.53850 . The Spearman's coefficient was highly significant at the 0.05 alpha level $\left(p_{\text {value }} 0.0384<0.05\right)$. The dependence was a positive one, which means there was the increased concentration of $\mathrm{Cd}$ in the environment with increased concentration of Cu. Similarly, the value of Spearman's rank correlation coefficient for concentration of dependencies between $\mathrm{Cd}$ and $\mathrm{Zn}$ was 0.60269. The Spearman's coefficient was highly significant at the 0.05 alpha level ( $p_{\text {value }} 0.0174<0.05$ ). The given dependence was a positive one, which means there was the increased concentration of $\mathrm{Cd}$ in the environment with increased concentration of $\mathrm{Zn}$. In the next year, in 2003, the value of the Spearman's rank correlation coefficient for the concentration of dependencies between $\mathrm{Cd}$ and As was 0.95589 . The Spearman's coefficient was highly significant at the 0.05 alpha level ( $p_{\text {value }} 0.0002<0.05$ ). The given dependence was a positive one, which means there was the increased concentration of $\mathrm{Cd}$ in the environment with increased concentration of As. Similarly, year 2003 was very interesting, same as in 2002, for the correlation $\mathrm{Cd}$ and $\mathrm{Cu}$. The most significant correlation between $\mathrm{Cd}$ and $\mathrm{Pb}$ was shown in 2004. The value of the Spearman's rank correlation coefficient for the concentration of dependencies between $\mathrm{Cd}$ and $\mathrm{Pb}$ was 0.96436 . The Spearman's coefficient was highly significant at the 0.05 alpha level $\left(p_{\text {value }} 0.0001<0.05\right.$ ). The given dependence was a positive one, which means there was the increased concentration of $\mathrm{Cd}$ in the environment with increased 
concentration of $\mathrm{Pb}$. Again, in 2005 it was very interesting for $\mathrm{As}, \mathrm{Cu}, \mathrm{Pb}$ and $\mathrm{Hg}, \mathrm{Zn}$. The value of Spearman's rank correlation coefficient for concentration of dependencies between Cd and Hg was 0.73126. The Spearman's coefficient was highly significant at the 0.05 alpha level ( $p_{\text {value }} 0.0393$ $<0.05$ ). The given dependence was a positive one, which means there was the increased concentration of $\mathrm{Cd}$ in the environment with increased concentration of $\mathrm{Hg}$. Similarly, the value of the Spearman's rank correlation coefficient for the concentration of dependencies between $\mathrm{Cd}$ and Zn was 0.77906 . The Spearman's coefficient was highly significant at the 0.05 alpha level ( $\left.p_{\text {value }} 0.0227<0.05\right)$. The given dependence was a positive one, which means there was the increased concentration of $\mathrm{Cd}$ in the environment with increased concentration of Zn. Again in 2008 and 2009, there were found positive dependencies between $\mathrm{Cd}$ and As, $\mathrm{Cu}$ and $\mathrm{Zn}$, where the Spearman's coefficient was significant at the 0.05 alpha level. These findings showed that the increase of $\mathrm{Cd}$ concentration in the environment was associated with the increased level of As, Cu, Zn. The most significant correlation between $\mathrm{Cd}$ and $\mathrm{As}, \mathrm{Pb}$ was shown in 2010. The Spearman's coefficient was highly significant at the 0.05 alpha level. The given dependence was a positive one, which means there was the increased concentration of $\mathrm{Cd}$ in the environment with increased concentration of As and $\mathrm{Pb}$. Cadmium is an interesting chemical element which is characterized by its dynamics, varied state in the environment and also its geochemical condition. Because of variations of geochemical background it is necessary to deal with a riskiness of increased content of various chemical elements, including cadmium. Salminen et al. (2005) states that the detected concentration of $\mathrm{Cd}$ is associated with many chemical elements and shows strong positive correlations with $\mathrm{Zn}, \mathrm{Pb}$ and $\mathrm{Cu}$. However, it shows a weak correlation with $\mathrm{As}, \mathrm{Hg}$. It points to the combined impact of mineralization, anthropogenic activities, mining, metallurgy and the impact of effluents from the urban agglomerations as well. Industry and mining of non-renewable resources form significant sources of toxic contamination of surface water, sediments and groundwater (Urminská, 2011; Resongles et al., 2014). Industrial and mining contamination may enter to the aquatic environment by atmospherically transported emissions which are subsequently deposited directly by dry or wet deposition into surface waters or may also be deposited indirectly by flush and leaching of soil deposits (Enfeng et al., 2010). Cadmium is an element accompanying lead in all enviornments and showing geochemical significance in relation to lead. $\mathrm{Cd}$ shows a similar pattern with $\mathrm{Cu}$ and $\mathrm{Hg}$ in the hypo-, meso- and epithermal deposits. Evidential significances were in relation to $\mathrm{Pb}$ and $\mathrm{Zn}$, as the elements are extensively bound to the sulphide minerals. The similar observations of heavy metals pollution of the environment and the correlation relationships between the chemical elements were reported by papers of Salminen et al. (2005), Kamala-Kannan et al. (2008), Andráš et al. (2013), Resongles et al. (2014). From the statistical processing of sediments data by the Spearman determined the dependencies between $\mathrm{Cd}$ and the following elements: $\mathrm{As}, \mathrm{Cu}, \mathrm{Hg}, \mathrm{Pb}$ and $\mathrm{Zn}$. The relations between $\mathrm{Cd}$ and the following elements: $\mathrm{Pb}, \mathrm{As}$ and $\mathrm{Cu}$ were very highly positive. Cadmium is a high risk factor in the environment. In industrialised countries there is a concern over anthropogenic accumulations of $\mathrm{Cd}$ in the environment, and it is classified as a potentially harmful element with respect to soil biological activity, plant metabolism and the health of humans and animals (KabataPendias and Pendias, 1992; Nguyen et al., 2005; Hegedűsová, et al., 2006; Khun et al., 2008; Resongles et al., 2014).

\section{References}

ANDRÁŠ, P. - KRNÁČ, J. - KHARBISH, S. - DIRNER, V. 2013. Distribúcia vybraných tažkých kovov na haldových poliach $\mathrm{Cu}$ ložiska L’ubietová. In Mineralia Slovaca, 2013, no. 45, 213-224. ISSN 0369-2086

BARANČÍKOVÁ, G. 1998. Návrh účelovej kategorizácie pol'nohospodárskych pôd Slovenska z hladiska ich citlivosti k znečisteniu t’ažkými kovmi. In Rostlinná výroba, vol. 44, 1998, no. 3, pp. 117-122.

ENFENG, L. - Jl, S. - LIYUAN, Y. - ENLOU, Z. - XIANGHUA, M. JIANJUN, W. 2010. Assessment of heavy metals contamination in the sediments of Nansihu Lake catchment, China. In Env. Monit \& Assess., 2010, no. 161, pp. 217-227.

FERGUSSON, J. E. 1990. The Heavy Elements, Chemistry, Environmental Impact and Health Effects. New Zeland : Pergamon Press, 1990, $614 \mathrm{p}$.

FIALA, K. 1999. Záväzné metódy rozborov pôd. Čiastkový monitorovací systém - pôda. Bratislava : VÚPOP, 1999, 142 p.

HEGEDÜSOVÁ, A. - HEGEDÜS, O. - MUSILOVÁ, J. 2006. Riziká kontaminácie pôd kadmiom. Nitra : UKF, ed. Príroda, 2006, 89 p.

KABATA - PENDIAS, A. - PENDIAS, H. 1992. Trace Elements in Soils and Plants. Florida: CRC Press, 1992, 365 p.

KAMALA-KANNAN, S. - PRABHU DASS BATVARI, B. - LEE, K. J. KANNAN, N. - KRISHNAMOORTHY, R. - SHANTHI, K. - JAYAPRAKASH, M. 2008. Assessment of heavy metals $(\mathrm{Cd}, \mathrm{Cr}$ and $\mathrm{Pb})$ in water, sediment and seaweed (Ulva lactuca) in the Pulicat Lake, South East India. In Chemosphere, vol. 71, 2008, no. 7, pp. 1233-1240.

KHUN, M. - ĎURŽA, O. - MILIČKA, J. - DLAPA, P. 2008. Environmentálna geochémia. Bratislava : Geo-grafika, 2008, 278 p. MAKOVNÍKOVÁ, J. - BARANČíKOVÁ, G. - DLAPA, P. - DERCOVÁ, K. 2006. Anorganické kontaminanty $v$ pôdnom ekosystéme. In Chemické lity, 2006, no.100, pp. 424-432.

NGUYEN, H. L. - LEERMAKERS, M. - OSÁN, J. - TÖRÖK, S. - BAEYENS, W. 2005. Heavy metals in lake Balaton: water column, suspended mater, sediment and biota. In Sc. of the Tot Environ., 2005, no. 340, pp. 213-230.

OBTULOVIČ, P. 2010. Bioštatistika. Nitra : SPU, 2010, pp.139-141. RESONGLES, E. - CASIOT, C. - FREUDIER, R. - DEZILEAU, L. - VIERS, J. - ELBAZ-PULICHET, F. 2014. Persisting impact of historical mining activity to metal $(\mathrm{Pb}, \mathrm{Zn}, \mathrm{Cd}, \mathrm{Tl}, \mathrm{Hg})$ and metalloid $(\mathrm{As}, \mathrm{Sb})$ enrichment in sediments of the Gordon river, Southern France. In Science of the total environment, vol. 481, 2014, pp. 509-521. DOI: 10.1016/j.scitotenv.2014.02.078

SALMINEN, R. - BATISTA, M. J. - BIDOVEC, M. - DEMETRIADES, A. - DE VIVO, B. et al. 2005. Geochemical Atlas of Europe. Part 1 - Background Information, Methodology and Maps. Brussels : EuroGeoSurveys Belgium, 2005, 525 p.

STEHLÍKOVÁ, B. 1999. Biometrika (Terminologický slovník). Nitra : SPU, 1999, $95 \mathrm{p}$.

ŠUTRIEPKA, M. 2006. http://www.banskeodpady.sk/files/ Michal\%20\%C5\%A0utriepka .pdf)>

URMINSKÁ, J. 2011. Riziko vplyvu vybraných tažkých kovov v sedimentoch sledovaných bansko-štiavnických vodných nádrží na životné prostredie. Habilitation thesis, Nitra : SPU, 2011, 177 p. 